\title{
FAKTOR-FAKTOR YANG MEMPENGARUHI INITIAL RETURN 1 HARI, RETURN 1 BULAN, DAN PENGARUH TERHADAP RETURN 1 TAHUN SETELAH IPO
}

\author{
Emilia $^{1}$; Lucky Sulaiman ${ }^{2}$; Roy Sembel ${ }^{3}$
}

\begin{abstract}
There are some anomalies happenning when the shares are traded in the secondary market or stock exchange. When the shares price at the secondary market is higher than the primary market, then we say that there is a positive initial return or underpricing happened. The opposite is negative initial return or overpricing.

The purpose of this research is to to study whether the underwriter's reputation, auditor's reputation, value of the share offering, percentage of the share offering, and earnings per share towards the IPO price influence the one day initial return, one month return, and one year return after the IPO. The objects of the research are 92 companies that went public through the Jakarta stock exchange market during 1999-2005 that had either positive or negative initial return. This research is done using multiple regression analysis with $F$ Test, $t$ Test, $R^{2}$ Test, and classic assumption testing.

The result indicates that only the value of the share offering variable that significantly influence the one day initial return and one month initial return negatively. For the one year return regression model, only the one month return that significantly influence the return one year after the IPO positively. It can be concluded that the higher the value of the share offering the smaller the one day initial return and one month initial return will be, and thus minimizing the positive initial return. Furthermore, the higher the one month initial return the higher also the one year return after the IPO.
\end{abstract}

Keywords: Initial Return, IPO, Return 1 Day, Return 1 Month, Return 1 Year.

\begin{abstract}
ABSTRAK
Ada beberapa anomali yang terjadi pada saat saham-saham diperdagangkan di pasar sekunder atau bursa efek. Apabila harga saham di pasar sekunder lebih tinggi dibanding harga saham di pasar perdana maka terjadi apa yang disebut positive initial return atau underpricing. Kebalikannya adalah negative initial return atau overpricing.

Tujuan dari penelitian ini adalah mengetahui apakah reputasi underwriter, reputasi auditor, nilai penawaran saham, prosentase penawaran saham, dan earnings per share terhadap harga IPO memiliki pengaruh terhadap initial return satu hari, return satu bulan, dan pengaruh terhadap return satu tahun sesudah IPO. Obyek penelitian ini terdiri dari 92 perusahaan yang go public di Bursa Efek Jakarta pada tahun 1999-2005 baik yang
\end{abstract}

${ }^{1,2,3}$ BINUS BUSINESS SCHOOL, BINUS UNIVERSITY, JWC Campus, Jl. Hang Lekir I No. 6, Kebayoran Baru, South Jakarta 12120, roy@roy-sembel.com 
mengalami positive initial return maupun negative initial return. Penelitian ini menggunakan analisis regresi berganda dengan Uji F, Uji t, Uji $R^{2}$, dan pengujian asumsi klasik.

Hasil penelitian menunjukkan hanya variabel nilai penawaran saham saja yang berpengaruh signifikan dan negatif terhadap initial return satu hari dan return satu bulan. Kemudian untuk model regresi Return 1 Tahun, hanya return satu bulan berpengaruh signifikan dan positif terhadap return satu tahun sesudah IPO. Dengan demikian dapat disimpulkan bahwa semakin tinggi nilai penawaran saham maka semakin rendah initial return satu hari dan return satu bulan sehingga memperkecil positive initial return. Selanjutnya, dengan semakin tinggi return satu bulan akan memperbesar return satu tahun sesudah IPO.

Kata Kunci : Initial Return 1 hari, return 1 bulan, return 1 tahun, reputasi underwriter dan auditor, nilai penawaran saham, prossentase penawaran saham, dan earnings per share terhadap harga IPO.

Kata Kunci: initial return, IPO, return 1 hari, return 1 bulan, return 1 tahun 


\section{PENDAHULUAN}

Perusahaan dalam rangka mengembangkan usahanya melakukan berbagai cara, diantaranya melakukan ekspansi. Untuk memenuhi kebutuhan ekspansi diperlukan suatu dana yang tidak sedikit. Hal ini menuntut manajemen untuk memilih apakah tambahan modal akan dilakukan dengan cara utang atau dengan menambah jumlah kepemilikan saham dengan penerbitan saham baru. Sebagaimana disebutkan dalam Roy Sembel (1996):

Capital is the bloodstream of the firms. There are several alternatives to acquire capital. Selling stock to the general public (the public offering) is one important alternative...

Ada beberapa cara yang dapat dilakukan perusahaan untuk memperolehnya, antara lain dengan: menjual kepada pemegang saham yang sudah ada, menjual kepada karyawan lewat ESOP (employee stock ownership plan), menambah saham lewat deviden yang tidak dibagi (dividend reinvestment plan), menjual langsung kepada pemilik tunggal (biasanya investor institusi) secara privat (private placement), atau menawarkan kepada publik. Proses penawaran sebagian saham perusahaan kepada masyarakat melalui bursa efek disebut go public.

Menurut Misnen Ardiansyah (2003), pada saat melakukan IPO, tidak ada harga pasar saham sampai dimulainya penjualan di pasar sekunder. Pada saat tersebut umumnya investor memiliki informasi terbatas seperti yang diungkapkan dalam prospektus yang memuat rincian informasi serta fakta material mengenai penawaran umum emiten baik berupa informasi keuangan maupun non-keuangan. Roy Sembel (1996) mengelompokkan investor menjadi dua grup : frequent investors yang berpartisipasi secara rutin dalam pasar IPO, dan new investors yang relatif baru terhadap pasar IPO tetapi memiliki pengalaman di pasar lain. Selanjutnya, Roy berasumsi bahwa frequent investors telah mempelajari benar mengenai mekanisme dan anomali seputar IPO. Pengetahuan tersebut akan menjadi landasan dalam penilaian akhir mereka dimana penilaian underwriter menjadi signifikan bagi frequent investors.

Harga saham pada penawaran perdana ditentukan berdasarkan kesepakatan antara perusahaan emiten dengan underwriter, sedangkan harga di pasar sekunder ditentukan oleh mekanisme pasar (permintaan dan penawaran). Apabila penentuan harga saham saat IPO secara signifikan lebih rendah dibandingkan dengan harga yang terjadi di pasar sekunder di hari pertama, maka terjadi underpricing. Besarnya underpricing diukur dengan initial return. Initial return yaitu return yang diperoleh pemegang saham di pasar perdana dan menjualnya di pasar sekunder hari pertama.

Dalam penelitian ini penulis tidak terlepas dari beberapa keterbatasan, diantaranya adalah sampel penelitian yang digunakan hanya terbatas pada perusahaan yang go public pada tahun 1999 sampai dengan 2005. Keterbatasan ini mungkin saja dapat menghasilkan beberapa hasil yang tidak diinginkan pada model penelitian.

Tujuan umum penelitian adalah untuk mengetahui pengaruh faktor-faktor seputar IPO terhadap kinerja saham sesudah IPO. Sedangkan secara khusus, penelitian dilakukan untuk mengetahui:

1. Pengaruh reputasi underwriter terhadap initial return 1 hari setelah IPO.

2. Pengaruh reputasi auditor terhadap initial return 1 hari setelah IPO.

3. Pengaruh nilai penawaran saham terhadap initial return 1 hari setelah IPO.

4. Pengaruh prosentase penawaran saham terhadap initial return 1 hari setelah IPO. 
5. Pengaruh earnings per share/harga IPO terhadap initial return 1 hari setelah IPO.

6. Pengaruh reputasi underwriter terhadap return 1 bulan setelah IPO.

7. Pengaruh reputasi auditor terhadap return 1 bulan setelah IPO.

8. Pengaruh nilai penawaran saham terhadap return 1 bulan setelah IPO.

9. Pengaruh prosentase penawaran saham terhadap return 1 bulan setelah IPO.

10. Pengaruh earnings per share/harga IPO terhadap return 1 bulan setelah IPO.

11. Pengaruh return 1 hari sesudah IPO terhadap return 1 tahun sesudah IPO.

12. Pengaruh return 1 bulan setelah IPO terhadap return 1 tahun sesudah IPO.

\section{LANDASAN TEORI}

Pengertian Pasar Modal menurut UU Pasar Modal No. 8 tahun 1995 adalah kegiatan yagn bersangkutan dengan penawaran umum dan perdagangan efek, perusahaan publik yang berkaitan dengan efek yang diterbitkannya, serta lembaga profesi yang berkaitan efek.

Ketika suatu perusahaan melakukan penawaran sahamnya untuk pertama kali atau Initial Public Offering (IPO), transaksi tersebut terjadi di pasar perdana. Harga yang terbentuk di pasar perdana ini merupakan kesepakatan antara pihak emiten dengan pihak penjamin emisi (underwriter). Kemudian saham-saham tersebut dapat diperdagangkan di pasar sekunder. Harga yang terbentuk di pasar ini sesuai dengan permintaan dan penawaran (mekanisme pasar).

Pada dasarnya pasar modal merupakan pasar sekunder sebab transaksi yang terjadi di pasar modal ini hanya antar investor. Dengan demikian dana yang didapatkan perusahaan melalui penjualan saham diperoleh dari hasil perdagangan antara perusahaan dengan investor di pasar perdana. Dengan kata lain perusahaan tidak akan memperoleh tambahan dana atas transaksi yang terjadi di pasar sekunder

\section{Go Public}

Menurut Eugene F. Brigham, Louis Gapenski, dan Michael C, Ehrhardt (2002:739), "Go public means selling some of a company's stock to outside investors and then letting the stock trade in public markets". Ketika suatu perusahaan memutuskan untuk go public maka ia akan melakukan penawaran saham perdana atau Initial Public Offerings (IPO).

Manfaat yang akan diperoleh perusahaan yang go public menurut Eugene F. Brigham, Louis Gapenski, dan Michael C. Ehrhardt (2002:739) adalah:

a. Memungkinkan pemilik perusahaan untuk melakukan diversifikasi usaha.

b. Meningkatkan likuiditas.

c. Memungkinkan perusahaan untuk memperoleh uang kas sewaktu-sewaktu.

d. Meningkatkan nilai perusahaan.

e. Menciptkan harga negosiasi ketika perusahaan hendak diakuisisi atau mengakuisisi perusahaan lain.

f. Meningkatkan pasar yang potensial karena pemegang saham, khususnya individu akan cenderung menjadi konsumen yang setia.

Disamping manfaat, perusahaan yang go public, terdapat pula kerugian yang dirasakan perusahaan sebagai konsekuensi go public :

a. Perusahaan harus melakukan pelaporan yang membutuhkan biaya yang tinggi.

b. Harus melakukan pengungkapan. 
c. Self-dealings yang biasanya dilakukan dalam perusahaan, misalnya meminimalkan hutang pajak penghasilan pribadi, menjadi sulit dilakukan.

d. Pasar yang lesu dan harga yang rendah (inactive market/low price) terjadi bila saham perusahaan tidak aktif diperdagangkan. Hal ini merugikan bila perusahaan berskala kecil sebab nilai pasar sahamnya tidak mencerminkan nilai saham yang sesungguhnya.

e. Berkurangnya pengendalian.

f. Harus menjaga hubungan dengan investor.

\section{Initial Return}

Initial return adalah selisih antara harga IPO dan harga saat saham listing di bursa. Saham yang dipasarkan di Bursa Efek Jakarta memiliki satuan nominal yang berbeda sementara aturan perubahan pergerakan perdagangan baru disesuaikan berikutnya. Nilai nominal saham yang tinggi relatif menghasilkan nilai prosentase initial return yang kecil walaupun secara nominal memiliki nilai yang sama.

Secara garis besar ada tiga anomali yang terjadi saat IPO saham. Anomali yang pertama adalah penurunan harga saham setelah saham IPO diperdagangkan di pasar modal. Fenomena inilah yang dikenal dengan underpricing atau positive initial return. Underpricing terjadi karena harga IPO yang ditetapkan terlalu rendah, sebab harga yang terjadi di pasar sekunder telah mencerminkan harga dalam kondisi keseimbangan (full information).

Anomali yang kedua adalah penurunan harga saham atau kinerja perusahaan yang telah menerbitkan saham dalam jangka panjang, sering disebut sebagai long-term underperformance. Roy Sembel (1996) yang menggunakan model WIPO untuk menjelaskan long-term underperformance mengemukakan:

...However, the IPO model can explain the long-term underperformance only up to some time between one to three years after offer date. The continuing downward drift of the long-term abnormal performance beyond that period is still a puzzle.

Demikian dijelaskan Ibotson et al (1994), Ritter (1991), Sembel (1996), Page dan Reyneke (1997), Teoh et al (1998), Alvarez dan Gonzales (1999), Basana (1999), Aggarwal et al (2000), Ritter (2000), Janice et al (2000), Bessler dan Theis (2002) dalam Dwi Martani (2003:1299), penurunan ditandai dengan menurunnya harga saham perusahaan dari waktu ke waktu dibandingkan kinerja pasar secara keseluruhan maupun kinerja industri.

Anomali yang ketiga adalah hot and cold market. Menurut Roy Sembel (1996), hot issues menjelaskan penawaran saham dengan initial return diatas rata-rata. Hot issues terjadi saat rata-rata initial return pada saat penawaran secara abnormal tinggi untuk jangka waktu yang diperpanjang.

\section{Penjamin Emisi Efek (Underwriter)}

Adapun tugas underwriter menurut dalam Dahlan Siamat (2004:249) adalah :

a. Memberikan nasihat mengenai:

- jenis efek yang sebaiknya dikeluarkan

- harga yang wajar untuk efek tersebut

- jangka waktu efek (obligasi dan sekuritas kredit)

b. Dalam mengajukan pernyataan pendaftaran emisi efek, membantu menyelesaikan tugas administrasi yang berhubungan dengan:

- pengisian dokumen pernyataan pendaftaran emisi efek 
- penyusunan prospektus

- merancang specimen efek

- mendampingi emiten selama proses evaluasi

c. Mengorganisasikan penyelenggaran emisi antara lain meliputi:

- pendistribusian efek

- menyiapkan sarana-sarana penunjang.

Beberapa jenis dan cara penjaminan emisi menurut Capital Market Directory dalam Dahlan Siamat (2004:267) adalah sebagai berikut :

a. Kesanggupan penuh (full commitment underwriting)

Full commitment atau sering juga disebut firm commitment underwriting yaitu suatu perjanjian penjamin emisi efek di mana penjamin emisi efek yang tidak laku terjual. Dari pengertian tersebut berlaku ketentuan bahwa underwriter berusaha menjual di pasar perdana kemudian membeli efek yang ternyata tidak laku terjual dengan harga yang sama dengan harga IPO pada pasar perdana. Ketentuan ini berlaku pada penjaminan emisi di pasar modal Indonesia. Lain halnya dengan di Amerika Serikat, pengertian full commitment berarti underwriter membeli seluruh saham emisi kemudian menjual kembali kepada investor dengan harga yang tentunya lebih tinggi.

b. Kesanggupan terbaik (best efforts commitment)

Dalam komitmen ini, underwiter akan berusaha semaksimal mungkin menjual efek-efek emiten. Apabila ada efek yang belum habis terjual, underwriter tidak wajib membelinya dan oleh karena itu mereka hanya membayar semua efek yang berhasil terjual dan mengembalikan sisanya kepada emiten.

c. Kesanggupan siaga (stand by commitment)

Penjamin emisi menurut komitmen ini adalah underwriter berusaha menawarkan efek semaksimalnya kepada investor. Kemudian apabila ada sisa yang belum terjual sampai batas waktu penawaran yang ditetapkan, underwriter menyanggupi membeli sisa efek tertentu dengan harga tertentu sesuai dengan perjanjian yang besarnya di bawah harga IPO pada pasar perdana.

d. Kesanggupan semua atau tidak sama sekali (all or none commitment)

Komitmen ini menyatakan bahwa apabila efek yang ditawarkan tersebut ternyata sebagian tidak terjual, maka penjualan efek tersebut dibatalkan sama sekali. Artinya bagian efek yang telah laku dipesan oleh investor akan dibatalkan.

\section{Auditor}

Dengan demkian, pelaksana auditing disebut sebagai auditor atau akuntan publik yang memiliki tugas-tugas sebagai berikut (Dahlan Siamat, 2004:252):

a. Melakukan pemeriksaan atas laporan keuangan perusahaan dan memberikan pendapatnya.

b. Memeriksa pembukuan, apakah sudah sesuai dengan prinsip akuntansi Indonesia dan ketentutan Bapepam.

c. Memberi petunjuk pelaksanaan cara-cara pembukuan yang baik (apabila diperlukan).

\section{Nilai Penawaran Saham}

Proceeds menunjukkan besarnya skala penawaran saham pada saat IPO. 


\section{Prosentase penawaran saham}

Leland \& Phyle dalam Daljono (2000) mengemukan prosentase kepemilikian yang ditahan oleh pemilik menunjukkan adanya private information yang dimiliki oleh pemilik/manajer.

\section{Earnings per Share (EPS)}

Laba per saham atau Earnings per Share mencerminkan informasi mengenai kemampuan perusahaan dalam menghasilkan arus kas yang baik di masa yang akan datang yang pada akhirnya akan meningkatkan pendapatan perusahaan

\section{METODOLOGI PENELITIAN}

Penelitian yang dilakukan oleh penulis meliputi perspektif-perspektif sebagai berikut:

1. Berdasarkan tingkat kristalisasi permasalahan

Penelitian yang dilakukan oleh penulis termasuk dalam penelitian formal (formal study) karena berawal dari batasan masalah dan hipotesis serta tujuan akhirnya adalah untuk menguji hipotesis menjawab batasan masalah.

2. Berdasarkan metode pengumpulan data

Penelitian ini dipandang sebagai studi pengamatan karena peneliti mengumpulkan data dengan melakukan pengamatan terhadap perusahaan- perusahaan yang melakukan IPO dengan mengunakan jasa underwriter.

3. Berdasarkan kemampuan peneliti terhadap variabel-variabel penelitian.

Penelitian ini berdesain ex post facto karena peneliti tidak mampu mempengaruhi variabel-variabel yang diteliti.

4. Berdasarkan tujuan penelitian

Penelitian ini bertujuan untuk mengetahui hubungan dan pengaruh antara reputasi underwriter(RUDW), reputasi auditor (RAUD), nilai penawaran saham (NPS), prosentase penawaran saham (PPS), dan Earnings per Share terhadap harga penawaran (EPS) pada return 1 hari setelah IPO (R1h), return 1 bulan setelah IPO (R1b). Serta hubungan serta korelasi antara return 1 hari setelah IPO (IR1h) dan return 1 bulan setelah IPO (R1b) terhadap return 1 tahun setelah IPO (R1t). Dengan demikian penelitian ini tergolong penelitian kausal.

5. Berdasarkan dimensi waktu

Penelitian ini dipandang sebagai studi cross sectional. Hal ini dikarenakan peneliti menggunakan data dari periode tahun 1999 sampai dengan tahun 2005.

6. Berdasarkan ruang lingkup topik pembahasan

Penelitian ini dipandang sebagai studi statistik. Hal ini dikarenakan penelitian ini dilakukan untuk mengetahui hubungan antara reputasi underwriter(RUDW), reputasi auditor (RAUD), nilai penawaran saham (NPS), prosentase penawaran saham (PPS), dan Earnings per Share terhadap harga penawaran(EPS) pada return 1 hari setelah IPO (IR1h) dan pada return 1 bulan setelah IPO (R1b) dengan menggunakan uji statistik. Kemudian dari hasil yang didapat selanjutnya persamaan return 1 hari setelah IPO (IR1h) dan return 1 bulan setelah IPO (R1b) diuji kembali untuk mengetahui pengaruh dan korelasinya terhadap return 1 tahun $(\mathrm{R} 1 \mathrm{t})$.

7. Berdasarkan ruang lingkup penelitian 
Penelitian ini tergolong penelitian berkondisi lapangan karena data yang digunakan benarbenar ada di lingkungan aktual.

\section{Variabel Penelitian}

Di dalam penelitian ini variabel-variabel yang akan digunakan yaitu:

\section{Variabel Dependen}

1. IR1h (Initial return pada hari pertama saham ditawarkan di pasar sekunder).

Besarnya initial return satu hari (IR1h), yaitu perbandingan antara selisih harga saham pada hari pertama penutupan (closing price) di pasar sekunder dengan harga saham pada penawaran perdana (offering price) dibagi dengan harga saham pada penawaran perdana (offering price).

2. R1b (Return pada satu bulan setelah saham ditawarkan di pasar sekunder).

Besarnya return satu bulan (R1b), yaitu perbandingan antara selisih harga saham pada satu bulan harga penutupan (closing price) di pasar sekunder dengan harga saham pada penawaran perdana (offering price) dibagi dengan harga saham pada penawaran perdana (offering price).

3. R1t (Return pada satu tahun setelah saham ditawarkan di pasar sekunder).

Besarnya return satu tahun(R1t), yaitu perbandingan antara selisih harga saham pada satu tahun harga penutupan (closing price) di pasar sekunder dengan harga saham pada penawaran perdana (offering price) dibagi dengan harga saham pada penawaran perdana (offering price).

\section{Variabel Independen}

a. Reputasi underwriter (RUDW)

Reputasi Underwriter diukur dengan melakukan pemeringkatan penjamin emisi (underwriter). Penjamin emisi yang dimaksud adalah penjamin utama emisi (lead underwriter) yang disebut juga penjamin pelaksana emisi. Pemeringkatan berdasarkan Caster-Manaster yang terdiri dari skala 0-9.

b. Reputasi auditor (RAUD)

Reputasi auditor diukur dengan melakukan pemeringkatan Kantor Akuntan Publik (KAP). Auditor yang termasuk big four ataupun dengan kantor akuntan affiliasi lokal diberi nilai 1, sedangkan yang tidak termasuk dalam big four akan diberikan nilai 0 .

c. Nilai penawaran saham (NPS)

Nilai penawaran saham yaitu hasil perkalian antara jumlah lembar saham yang ditawarkan pada saat IPO dengan harga penawaran, kemudian di-log agar nilainya tidak terlalu besar untuk dimasukkan dalam model persamaan.

d. Prosentase Penawaran Saham (PPS)

Prosentase penawaran saham merupakan proporsi nilai penawaran saham terhadap total ekuitas pada tahun sebelum IPO.

e. Earnings per Share/harga IPO (EPSP)

Variabel ini merupakan laba bersih pada tahun terakhir sebelum perusahaan listing dibagi dengan jumlah saham penawaran. Kemudian nilai tersebut dibagi lagi dengan harga IPO. 
Tabel 1. Variabel - variabel

\begin{tabular}{|c|l|c|c|c|}
\hline NO & \multicolumn{1}{|c|}{ NAMA VARIABEL } & JENIS VARIABEL & SIMBOL & SKALA \\
\hline 1 & Initial Return 1 hari, Return 1 bulan & $\begin{array}{c}\text { Dependen, } \\
\text { Independen }\end{array}$ & IR1h, R1b & Rasio \\
\hline & Return 1 tahun & Dependen & R1t & Rasio \\
\hline 2 & Reputasi Underwriter & Independen & RUDW & $\begin{array}{c}\text { Nominal(dalam bentuk } \\
\text { dummy) }\end{array}$ \\
\hline 3 & Reputasi Auditor & Independen & RAUD & $\begin{array}{c}\text { Nominal(dalam bentuk } \\
\text { dummy) }\end{array}$ \\
\hline 4 & Nilai penawaran saham & Independen & NPS & Nominal log \\
\hline 5 & Prosentase penawaran saham & Independen & PPS & Rasio \\
\hline 6 & Earnings Per Share/harga penawaran & Independen & EPSP & Rasio \\
\hline
\end{tabular}

\section{Teknik Pengumpulan Data}

Data yang digunakan dalam penelitian ini adalah data sekunder. Pengumpulan data dilakukan dengan observasi. Berikut ini adalah data yang dikumpulkan:

IR1h : offering price dan closing price 1 hari

$\mathrm{R} 1 \mathrm{~b} \quad$ : offering price dan closing price 1 bulan.

R1t : offering price dan closing price 1 tahun

RUDW : nama underwriter tiap emiten, peringkat penjamin emisi.

RAUD : nama auditor tiap emiten, peringkat auditor.

NPS : jumlah saham yang ditawarkan saat IPO, harga penawaran.

PPS : nilai penawaran saham, total ekuitas satu tahun sebelum listing.

EPSP : laba bersih 1 tahun sebelum IPO, jumlah dan harga saham ditawarkan

Tabel 2. Proses Pemilihan Sampel

\begin{tabular}{|ll|}
\hline Jumlah perusahaan yang melakukan IPO tahun 1999-2005 di BEJ & 101 \\
\hline Jumlah perusahaan yang tidak memiliki underwriter & $(3)$ \\
\hline Jumlah perusahaan yang data keuangannya tidak lengkap & $(6)$ \\
\hline Jumlah perusahaan yang menjadi obyek penelitian & 92 \\
\hline
\end{tabular}

Tabel 3. Ikhtisar Jumlah Sampel Berdasarkan Tahun

\begin{tabular}{|l|l|l|}
\hline NO & Tahun Penelitian & Jumlah Perusahaan \\
\hline 1 & 1999 & 6 \\
\hline 2 & 2000 & 19 \\
\hline 3 & 2001 & 28 \\
\hline 4 & 2002 & 20 \\
\hline 5 & 2003 & 6 \\
\hline 6 & 2004 & 10 \\
\hline 7 & 2005 & 3 \\
\hline
\end{tabular}




\section{Teknik Analisis Data}

\section{Variabel Dependen}

1. Initial Return 1 hari setelah IPO diukur dengan nilai return selama 1 hari sesudah IPO pada harga penutupan. Untuk menghitung initial return hari pertama sesudahIPO pada harga penutupan digunakan persamaan sebagai berikut:

$$
\text { IR } 1 \mathrm{~h}=\frac{\mathrm{P} 1-\mathrm{P} 0}{\mathrm{P} 0}
$$

IR1h $=$ InitialReturn hari ke 1.

$\mathrm{P} 1=$ Harga saham hari ke 1 penutupan (closing price) di pasar sekunder.

$\mathrm{P} 0=$ Harga saham pada penawaran perdana (offering price).

2. Return 1 bulan setelah IPO diukur dengan nilai return selama 1 bulan sesudah IPO pada harga penutupan. Untuk menghitung return satu bulan sesudahIPO pada harga penutupan digunakan persamaan sebagai berikut:

$$
\begin{array}{ll}
\mathrm{R} 1 \mathrm{~b}=\frac{\mathrm{P} 30-\mathrm{P} 0}{\mathrm{P} 0} & \\
\mathrm{R} 1 \mathrm{~b}= & \text { Return 1 bulan. } \\
\mathrm{P} 30= & \text { Harga saham penutupan (closing price) di pasar sekunder satu } \\
\mathrm{P} 0 \quad=\quad \text { Harga saham pada penawaran perdana (offering price). }
\end{array}
$$

3. Return 1 tahun setelah IPO diukur dengan nilai return selama 1 tahun sesudah IPO pada harga penutupan. Untuk menghitung return satu tahun sesudah IPO pada harga penutupan digunakan persamaan sebagai berikut:

$$
\mathrm{R} 1 \mathrm{t}=\frac{\mathrm{P} 360-\mathrm{P} 0}{\mathrm{P} 0}
$$

R1t $=$ Return 1tahun.

P360 = Harga saham penutupan (closing price) di pasar sekunder satu

$\mathrm{P0}=\quad$ Harga saham pada penawaran perdana (offering price).

\section{Variabel Independen}

a. Reputasi Auditor (RAUD)

Jika auditor yang digunakan oleh emiten termasuk dalam big four maka akan diberikan nilai 1, sedangkan yang tidak termasuk dalam peringkat tersebut akan diberikan nilai 0 .

b. Reputasi underwriter(RUDW)

Pemeringkatan underwriter yang digunakan dengan menggunakan Caster- Manaster diberi skala mulai dari 9-0. dimana data underwriter ini didapat dari peneliti sebelumnya dimana peneliti meneliti reputasi underwriter dari perusahaan yang akan go-public dari tahun 1999-2005.

c. Nilai penawaran saham 
Nilai penawaran saham yaitu hasil perkalian antara jumlah lembar saham yang ditawarkan pada saat IPO dengan harga penawaran, kemudian di-log agar nilainya tidak terlalu besar untuk dimasukkan dalam model persamaan.

$$
\mathrm{NPS}=\log (\text { shares } \mathrm{X} \text { offer price })
$$

d. Prosentase penawaran saham

Prosentase penawaran saham dihitung dengan membagi nilai penawaran saham dengan total ekuitas satu tahun sebelum IPO.

$$
\text { PPS }=\text { NPS / total ekuitas }
$$

e. Earnings per Share/harga penawaran

$$
\mathrm{EPSP}=(\text { Laba bersih } / \text { jumlah penawaran saham }) / \mathrm{P} 0
$$

Adalah rasio antara laba bersih pada tahun terakhir sebelum perusahaan listing dengan jumlah penawaran saham perusahaan terhadap harga IPO (P0).

\section{Analisis Regresi Berganda}

Analisis regresi berganda digunakan untuk mengetahui ketergantungan variabel dependen (terikat) dengan satu atau lebih variabel independen (variabel penjelas/bebas). Selain itu analisis regresi ini juga menunjukkan arah hubungan antara variabel dependen dengan variabel independen.

Persamaan regresi berganda yang terbentuk adalah :

$$
\mathrm{IR} \mathrm{h}_{\mathrm{t}}=\mathrm{a}+\mathrm{b} 1 \mathrm{RUDW} \mathrm{t}_{\mathrm{t}}+\mathrm{b} 2 \mathrm{RAUD}_{\mathrm{t}}+\mathrm{b} 3 \log (\mathrm{NPS})_{\mathrm{t}}+\mathrm{b} 4 \mathrm{PPS}_{\mathrm{t}}+\mathrm{b} 5 \mathrm{EPSP}_{\mathrm{t}}+\varepsilon_{\mathrm{t}}
$$

$\begin{array}{ll}\text { RUDW } & =\text { reputasi underwriter } \\ \text { RAUD } & =\text { reputasi auditor } \\ \text { NPS } & =\text { nilai penawaran saham } \\ \text { PPS } & =\text { prosentase penawaran saham } \\ \text { EPSP } & =\text { earnings per share/harga IPO } \\ \mathrm{a} & =\text { konstanta } \\ \mathrm{b} 1 \ldots 5 & =\text { koefisien regresi dari variabel independen } \\ \varepsilon & =\text { residu } \\ \mathrm{t} & =\text { periode penelitian }\end{array}$

Persamaan regresi berganda yang terbentuk adalah :

\begin{aligned} &${\mathrm{R} 1 b_{\mathrm{t}}=\mathrm{a}+\mathrm{b} 1 \mathrm{RUDW}_{\mathrm{t}}+\mathrm{b} \text { RAUD }_{\mathrm{t}}+\mathrm{b} 3 \log (\mathrm{NPS})_{\mathrm{t}}+\mathrm{b}} \\ &$\hline Di mana : R1b $=$ return 1 bulan setelah IPO \\ & RUDW $=$ reputasi underwriter \\ & RAUD $=$ reputasi auditor \\ & NPS $=$ nilai penawaran saham \\ & PPS $=$ prosentase penawaran saham \end{aligned}




$\begin{array}{ll}\mathrm{EPSP} & =\text { earnings per share/harga IPO } \\ \mathrm{a} & =\text { konstanta } \\ \mathrm{b} 1 \ldots 5 & =\text { koefisien regresi dari variabel independen } \\ \varepsilon & =\text { residu } \\ \mathrm{t} & =\text { periode penelitian }\end{array}$

Hasil persamaan regresi di atas akan diuji dengan Uji $\mathrm{F}$, Uji t, Uji $\mathrm{R}^{2}$, dan pengujian asumsi klasik (normalitas, multikolinieritas, autokorelasi) sebagai berikut :

a. Uji Keberartian Model (Uji F)

Uji F pada dasarnya digunakan untuk melihat signifikansi mpdel regresi,yaitu apakah model tersebut layak dipakai/tidak untuk menganalisa apakah semua variabel independen yang dimasukkan dalam model mempunyai pengaruh secara bersamasama terhadap variabel dependen.

Dasar pengambilan keputusan dengan menggunakan program SPSS 12 adalah sebagai berikut :

(1) Jika nilai sig-F $>0.05$ berarti secara bersama-sama variabel independen tidak mempunyai hubungan signifikan dengan variabel dependen.

(2) Jika nilai sig-F $<0.05$ berarti secara bersama-sama variabel independen mempunyai hubungan signifikan dengan variabel dependen.

b. Uji Koefisien Regresi (Uji t)

Uji statistik t pada dasarnya digunakan untuk menentukan apakah koefisien regresi variabel independen yang diuji signifikan/tidak signifikan. Kriteria yang digunakan dalam menentukan suatu variabel signifikan/tidak signifikan dengan menggunakan program SPSS 12.00 adalah sebagai berikut :

Dari tabel Coefficients akan diperoleh nilai t hitung dan sig-t untuk masing-masing variabel independen yang diuji. Bandingkan nilai sig-t dengan 0.05 .

Dasar pengambilan keputusan :

(1) Jika sig-t $>0.05$ berarti variabel independen tidak mempunyai hubungan signifikan dengan variabel dependen.

(2) Jika sig-t $<0.05$ berarti variabel independen mempunyai hubungan signifikan dengan variabel dependen.

c. Koefisien Determinasi $\left(\mathrm{R}^{2}\right)$

Koefisien determinasi mengukur besar proporsi (persentase) dari jumlah ragam $Y$ yang diterangkan oleh model regresi atau untuk mengukur besar sumbangan variabel penjelas $\mathrm{X}$ terhadap ragam variabel respon $\mathrm{Y}$.

Nilai koefisien determinasi berkisar $0 \leq \mathrm{R}^{2} \leq 1$.

d. Uji Asumsi Klasik

(1) Normalitas

Uji normalitas dilakukan untuk melihat apakah data yang dianalisis memiliki

nilai residual di sekitar nol (data normal). Dalam penelitian ini untuk

menguji apakah data berdistribusi normal atau tidak dilakukan dengan analisis grafik.

Dasar pengambilan keputusan :

(a) Jika data menyebar di sekitar garis diagonal dan mengikuti arah garis diagonal, maka model regresi memenuhi asumsi normalitas.

(b) Jika data menyebar jauh dari garis diagonal dan/atau tidak mengikuti arah garis diagonal, maka model regresi tidak memenuhi asumsi normalitas. 
(2) Multikolinieritas

Multikolinier terjadi jika terdapat korelasi sangat tinggi antar variabel independen. Uji multikolinieritas bertujuan untuk menguji apakah pada model regresi ditemukan adanya korelasi antar variabel independen. Model regresi yang baik seharusnya tidak terjadi korelasi di antara variabel independen. Adanya multikolinieritas dapat dilihat dari nilai tolerance atau VIF (Variance Inflation Factor) dari masing-masing variabel.

Dasar pengambilan keputusan :

(a) Jika nilai tolerance $<0.1$ atau VIF $>10$ maka terdapat multikolinieritas.

(b) Jika nilai tolerance $>0.1$ atau VIF $<10$ maka tidak terdapat multikolinieritas.

(3) Autokorelasi

Uji autokorelasi, bertujuan menguji apakah dalam suatu model regresi linear ada korelasi antara kesalahan pengganggu(nilai residu) pada periode $t$ dengan kesalahan pada periode t-1 (sebelumnya). Jika terjadi korelasi, maka dinamakan ada masalah autokorelasi. Model regresi yang baik adalah regresi yang bebas dari autokorelasi.

Dasar pengambilan keputusan untuk mendeteksi ada atau tidaknya autokorelasi adalah :

(a) Bila nilai Durbin Watson (DW) terletak diatas critical value $\mathrm{D}\left(\mathrm{d}_{\mathrm{U}}\right)$, maka koefisien autokorelasi sama dengan nol, berarti tidak ada autokorelasi.

(b) Bila nilai DW lebih rendah daripada critical value $\mathrm{D}\left(\mathrm{d}_{\mathrm{L}}\right)$, maka koefisien autokorelasi lebih besar daripada nol, berarti ada autokorelasi positif.

(c) Bila nilai DW terletak diantara batas atas (du) dan batas bawah (dl), maka hasilnya tidak dapat disimpulkan.

Selanjutnya akan dilakukan penelitian untuk mengetahui korelasi dari initial return satu hari dan return satu bulan terhadap return satu tahun seberapa besar hubungan dari initial return 1 hari dan return 1 bulan terhadap return 1 tahun:

$$
\mathrm{R} 1 \mathrm{t}_{\mathrm{t}}=\mathrm{a}+\mathrm{b} 1 \mathrm{IR} 1 \mathrm{~h}_{\mathrm{t}}+\mathrm{b} 2 \mathrm{R} 1 \mathrm{~b}_{\mathrm{t}}+\varepsilon_{\mathrm{t}}
$$

Dimana :

$\begin{array}{rll}\mathrm{R} 1 \mathrm{t} & = & \text { return } 1 \text { tahun setelah IPO } \\ \mathrm{a} & = & \text { konstanta } \\ \mathrm{b} 1 . .2 & = & \text { koefisien regresi dari variabel independen } \\ \varepsilon & = & \text { residu } \\ \mathrm{t} & = & \text { periode penelitian }\end{array}$

\section{ANALISIS DAN PEMBAHASAN}

Peneliti menggunakan data perusahaan go public yang listing di Bursa Efek Jakarta pada tahun 1999-2005. Data perusahaan tersebut diperoleh dari www.jsx.co.id dan www.ebursa.com. Jumlah keseluruhan perusahaan yang listing di Bursa Efek Jakarta pada tahun 1999-2005 adalah 101. Dari jumlah tersebut, peneliti hanya akan mengambil jumlah perusahaan yang memiliki kelengkapan data yaitu berjumlah 92 perusahaan. 


\section{Penentuan Nilai Variabel}

Beberapa tahapan-tahapan penelitian telah dilakukan dalam penentuan nilai variabel dependen dan independen, yaitu :

1. Penentuan nilai variabel dependen sekaligus independen initial return 1 hari (IR1h) yang dihitung berdasarkan selisih harga saham penutupan pada hari pertama tercatat di Bursa Efek Jakarta (P1) dengan harga saham pada saat penawaran perdana (P0).

2. Penentuan nilai variabel dependen sekaligus independen return 1 bulan (R1b) yang dihitung berdasarkan selisih harga saham penutupan pertama setelah 1 bulan tercatat di Bursa Efek Jakarta (P30) dengan harga saham pada saat penawaran perdana (P0).

3. Penentuan nilai variabel dependen return 1 tahun (R1t) yang dihitung berdasarkan selisih harga saham penutupan pertama setelah 1 tahuntercatat di Bursa Efek Jakarta (P360) dengan harga saham pada saat penawaran perdana (P0).

4. Penentuan nilai variabel dummy reputasi underwriter (RUDW) berdasarkan peringkat underwriter Caster-Manaster dalam artikel Roy Sembel \& Pahala. Dalam artikel tersebut, peringkat underwriter dikelompokkan dalam skala 0-9 dimana nilai 0 untuk underwriter yang memiliki reputasi paling rendah dan nilai 9 untuk underwriter dengan reputasi paling tinggi. Adapun underwriter diluar peringkat tersebut akan diberikan nilai 0.

5. Penentuan nilai variabel dummy reputasi auditor (RAUD) berdasarkan klasifikasi KAP big four dan non-big four. Dimana untuk perusahaan yang menggunakan auditor dari KAP big four akan diberikan nilai 1 dan nilai 0 untuk kebalikannya.

6. Penentuan nilai variabel independen nilai penawaran saham (NPL) yang dihitung berdasarkan harga saham perdana dikalikan dengan jumlah lembar saham pada saat penawaran perdana.

7. Penentuan nilai prosentase penawaran saham (PPS) berdasarkan nilai penawaran saham dibagi total ekuitas 1 tahunsebelum listing.

8. Penentuan nilai variabel Earnings per Share/harga IPO (EPSP) yang dihitung berdasarkan laba bersih perusahaan 1 tahunsebelum listing dibagi dengan jumlah lembar saham beredar. Setelah itu EPS dibagi harga saham IPO.

Tabel 4. Descriptive Statistics

\begin{tabular}{|l|l|l|l|l|l|}
\hline & $\mathrm{N}$ & Minimum & Maximum & Mean & Std. Deviation \\
\hline NPS & 92 & 9.8921 & 12.6200 & 10.622575 & .5471034 \\
PPS & 92 & -1.0907 & 9.6000 & .743496 & 1.1048942 \\
EPSP & 92 & -2.1909 & 48.2332 & 1.166054 & 6.0196763 \\
IR1h & 92 & -.7500 & 3.4500 & .435631 & .6483139 \\
R1b & 92 & -.7457 & 5.5000 & .594537 & 1.1182872 \\
R1t & 89 & -.9524 & 6.1333 & .201031 & 1.1607433 \\
Valid N (listwise) & 89 & & & & \\
\hline
\end{tabular}

Tabel diatas menunjukkan dengan nilai rata-rata untuk variabel NPS adalah 10.622575 dengan nilai tertinggi 12.6200 dan terendah 9.8921. Standar deviasi NPS adalah 0.5471034 . Dengan range antara nilai tertinggi dan terendah yang mendekati nilai rata-rata, variabel NPS memiliki standar deviasi yang tinggi. Selanjutnya, variabel PPS memiliki nilai rata-rata 0.7435 dengan nilai tertinggi 9.6 dan terendah -1.0907. Sedangkan, standar deviasi 
variabel PPS cukup tinggi yaitu 1.1049. Variabel EPSP memilki nilai rata-rata 1.1661 dengan range cukup jauh dengan nilai tertinggi 48.2332 dan nilai terendah -2.1909. Kondisi tersebut juga tercerminkan oleh nilai standar deviasi yang tinggi yaitu 6.0197.

Untuk variabel dependen $\mathrm{R} 1 \mathrm{~h}$, diketahui nilai rata-rata adalah 0.4356 dengan nilai tertinggi 3.4500 dan nilai terendah -0.7500 . Variabel R1h memiliki standar deviasi yang tinggi yaitu 0.6483 . Selanjutnya, variabel R1b memiliki nilai rata-rata 0.5948 dengan standar deviasi hampir dua kali yaitu 1.1183. Demikian nilai tertinggi R1b pada 5.5000 dan nilai terendah pada -0.7457. Variabel R1t, yang hanya melibatkan penelitian pada tahun 1999 sampai 2004, memiliki nilai rata-rata 0.2010 . Dengan standar deviasi 1.1607 , nilai tertinggi variabel R1t adalah 6.1333 dan nilai terendah -0.9524 .

Tabel 5. Nilai Variabel

\begin{tabular}{|l|l|l|l|l|l|l|}
\hline VARIABEL & NPS & PPS & EPSP & R1h & R1b & R1t \\
\hline Tahun 1999 & & & & & & \\
\hline Rata-rata & 10.6826 & 0.7401 & 0.0286 & 0.5190 & 0.4319 & -0.4057 \\
\hline Standard deviasi & 0.3852 & 0.2531 & 0.0246 & 0.4973 & 0.4203 & 0.3049 \\
\hline Tahun 2000 & & & & & & \\
\hline Rata-rata & 10.7742 & 0.7237 & 0.3432 & 0.3648 & 0.2092 & -0.2641 \\
\hline Standard deviasi & 0.4408 & 0.7694 & 0.4873 & 0.6962 & 0.8716 & 0.5377 \\
\hline Tahun 2001 & & & & & & \\
\hline Rata-rata & 10.3480 & 0.9677 & 0.1746 & 0.7521 & 1.0023 & 0.2367 \\
\hline Standard deviasi & 0.3472 & 1.7464 & 0.6310 & 0.8744 & 1.5075 & 0.9413 \\
\hline Tahun 2002 & & & & & & \\
\hline Rata-rata & 10.4811 & 0.6129 & 0.3059 & 0.2962 & 0.7680 & 0.4197 \\
\hline Standard deviasi & 0.4386 & 0.4391 & 0.4736 & 0.3368 & 1.1027 & 1.2715 \\
\hline Tahun 2003 & & & & & & \\
\hline Rata-rata & 11.4413 & 0.5783 & 0.7077 & 0.1159 & 0.1910 & 0.4676 \\
\hline Standard deviasi & 1.0750 & 0.4080 & 0.6184 & 0.1138 & 0.2323 & 0.5775 \\
\hline Tahun 2004 & & & & & & \\
\hline Rata-rata & 10.8658 & 0.5573 & 8.4271 & 0.1908 & 0.3584 & 0.7516 \\
\hline Standard deviasi & 0.5361 & 1.1020 & 17.2653 & 0.2289 & 0.6154 & 2.2563 \\
\hline Tahun 2005 & & & & & & \\
\hline Rata-rata & 10.6003 & 0.6046 & 0.3539 & 0.1483 & -0.0085 & \\
\hline Standard deviasi & 0.2651 & 0.1003 & 0.2170 & 0.2862 & 0.3462 & \\
\hline
\end{tabular}

Tabel diatas menunjukkan untuk nilai penawaran saham paling tinggi terjadi pada tahun 2003. Demikian halnya dengan standar deviasi NPS 2003 merupakan yang tertinggi. Namun PPS tertinggi terjadi pada tahun 2001. Hal ini bisa dikarenakan pada tahun 2003 hanya terdapat 6 perusahaan yang IPO dimana tiga diantaranya adalah BUMN (Bank Rakyat Indonesia, Bank Mandiri, dan Perusahaan Gas Negara). Ketiga BUMN memiliki nilai penawaran saham tertinggi diantara ke-92 sampel perusahaan. Namun, dikarenakan dua dari tiga BUMN tersebut adalah bank maka untuk rasio financial leverage memang lebih tinggi dari industri lain. Sehingga wajar saja jikalau NPS tertinggi terjadi pada tahun 2003 dengan rasio PPS kedua terkecil. 
IR1h dan R1b tertinggi terdapat pada tahun 2001 yaitu 0.7521 dan 1.0023 . Akan tetapi rata-rata R1t tertinggi dialami oleh perusahaan-perusahaan yang IPO di tahun 2004. Hal ini dapat dikarenakan oleh membaiknya perekonomian nasional pada tahun 2005.

Tabel 6. Lead Underwriter \& Auditor

\begin{tabular}{|l|l|l|l|l|}
\hline \multirow{2}{*}{ TAHUN } & \multicolumn{2}{|c|}{ Lead Underwriter } & \multicolumn{2}{c|}{ Auditor } \\
\cline { 2 - 5 } & Bereputasi 9-5 & Bereputasi 4-0 & Big Four & Non-big Four \\
\hline 1999 & 6 & 0 & 4 & 2 \\
2000 & 19 & 0 & 16 & 3 \\
2001 & 25 & 3 & 14 & 14 \\
2002 & 19 & 1 & 7 & 13 \\
2003 & 6 & 0 & 4 & 2 \\
2004 & 5 & 5 & 5 & 5 \\
2005 & 3 & 0 & 0 & 3 \\
\hline \multirow{2}{*}{ Total } & 83 & 9 & 50 & 42 \\
\cline { 2 - 5 } & & 92 & & 92 \\
\hline
\end{tabular}

Melalui Tabel diatas diketahui bahwa terdapat 83 perusahaan menggunakan lead underwriter dengan reputasi antara 9-5 sedangkan hanya 9 perusahaan yang mengunakan lead underwriter dengan reputasi antara 4-0. Dengan demikian, dapat disimpulkan bahwa sebagian besar sampel penelitian terdiri dari perusahaan yang menggunakan underwriter yang bereputasi baik.

Sedangkan untuk reputasi auditor, terdapat 50 perusahaan menggunakan jasa auditor dari KAP big-four. Sisanya 42 perusahaan lainnya tidak menggunakan jasa auditor dari KAP big-four. Sehingga tidak terdapat perbedaan yang cukup signifikan antara proporsi perusahaan dengan auditor bereputasi dan tidak bereputasi.

\section{Model Regresi Iniitial Return 1 Hari}

$$
\begin{aligned}
\text { IR1 }_{t}= & 5.069+\text { 0.010RUDW }_{t}+0.081 R A U D_{t}-\text { 0.442NPS }_{t}-\text { 0.058PPS }_{t} \\
& -0.007 \text { EPSP }_{t}+\varepsilon_{t}
\end{aligned}
$$

\section{Uji Keberartian Model (Uji F)}

Tabel 7. Uji Keberartian Model

\begin{tabular}{|ll|l|l|l|l|l|}
\hline Model & Sum of Squares & df & Mean Square & F & Sig. \\
\hline 1 & Regression & 4.843 & 5 & .969 & 2.494 & $.037(\mathrm{a})$ \\
& Residual & 33.405 & 86 & .388 & & \\
& Total & 38.248 & 91 & & & \\
\hline
\end{tabular}

a Predictors: (Constant), EPSP, NPS, PPS, RUDW, RAUD

b Dependent Variable: IR1h 
Melalui Tabel diatas, diketahui bahwa nilai probabilitas $\mathrm{F}$ lebih kecil dari $\alpha=0.05$ maka secara bersama-sama variabel independen mempunyai hubungan yang signifikan dengan variabel dependen.

\section{Uji Koefisien Regresi (Uji t)}

Tabel 8. Uji Koefisien Regresi

\begin{tabular}{|c|l|l|l|l|l|l|}
\hline \multirow{2}{*}{ Model } & & \multicolumn{2}{l|}{$\begin{array}{l}\text { Unstandardized } \\
\text { Coefficients }\end{array}$} & $\begin{array}{l}\text { Standardized } \\
\text { Coefficients }\end{array}$ & $\mathrm{t}$ & Sig. \\
\hline & & $\mathrm{B}$ & Std. Error & Beta & & \\
\hline 1 & (Constant) & 5.069 & 1.442 & & 3.514 & .001 \\
& RUDW & .010 & .036 & .031 & .276 & .783 \\
& RAUD & .081 & .154 & .063 & .525 & .601 \\
& NPS & -.442 & .135 & -.373 & -3.267 & .002 \\
& PPS & -.058 & .060 & -.099 & -.967 & .336 \\
& EPSP & -.007 & .012 & -.066 & -.612 & .542 \\
\hline
\end{tabular}

a Dependent Variable: IR1h

Hasil uji t menunjukkan untuk variabel reputasi underwriter (RUDW) memiliki hubungan positif yang tidak signifikan dengan IR1h karena probabilitas RUDW lebih besar dari $\alpha$. Demikian halnya dengan variabel reputasi auditor memiliki hubungan positif yang tidak signifikan dengan IR1h. Sedangkan untuk variabel NPS, EPSP, dan PPS memiliki hubungan negatif terhadap IR1h. Secara keseluruhan, semua variabel indepeden tidak memiliki hubungan yang signifikan terhadap variabel dependen IR1h kecuali variabel NPS yang memilki probabilitas 0.002 lebih kecil dari $\alpha=0.05$.

\section{Uji Koefisien Determinasi $\left(\mathbf{R}^{2}\right)$}

Tabel dibawah menunjukkan bahwa nilai R2 adalah sebesar 0.127 . Hal ini berarti $12.7 \%$ variasi variabel independen dapat menjelaskan variabel dependen IR1h, sedangkan sisanya $87.3 \%$ dijelaskan oleh variabel lain.

Tabel 9. Uji Koefisien Determinasi

\begin{tabular}{|l|l|l|l|l|}
\hline Model & R & R Square & Adjusted R Square & Std. Error of the Estimate \\
\hline 1 & .356 (a) & .127 & .076 & .6232400 \\
\hline
\end{tabular}

a Predictors: (Constant), EPSP, NPS, PPS, RUDW, RAUD

b Dependent Variable: IR1h 


\section{Uji Asumsi Klasik}

a. Normalitas

Normal P-P Plot of Regression Standardized Residual

Dependent Variable: IR1h

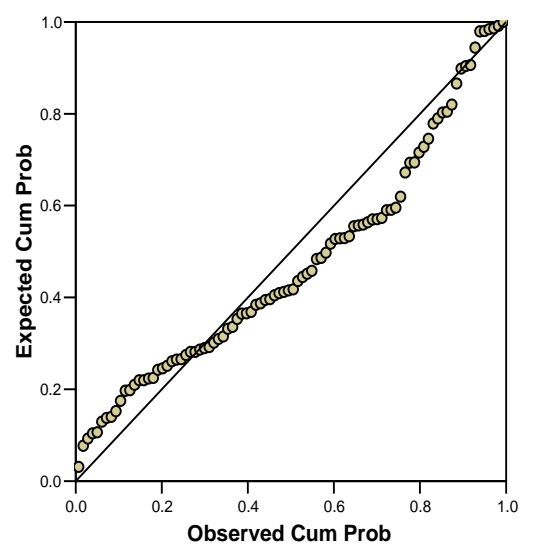

Pada grafik diatas diperlihatkan tingkat penyebaran titik-titik sekitar garis diagonal mengikuti arah garis diagonal. Sehingga model regresi Initial Return 1 Hari telah memenuhi asumsi normalitas.

\section{b. Multikolinearitas}

Tabel 10. Multikolinearitas

\begin{tabular}{|l|l|l|l|}
\hline Model & & \multicolumn{2}{|c|}{ Collinearity Statistics } \\
\hline & & Tolerance & VIF \\
\hline 1 & (Constant) & & \\
& RUDW & .819 & 1.221 \\
& RAUD & .715 & 1.398 \\
& NPS & .778 & 1.286 \\
& PPS & .962 & 1.040 \\
& EPSP & .861 & 1.161 \\
\hline
\end{tabular}

a Dependent Variable: IR1h

Hasil uji multikolinieritas didapatkan bahwa untuk semua variabel independen (RUDW, RAUD, NPS, PPS, EPSP) memiliki nilai tolerance yang lebih besar dari 0.1 dan VIF lebih kecil dari 10. Dengan demikian, bisa disimpulkan bahwa model regresi Initial Return 1 Hari tidak memilki masalah dengan multikolinieritas antara variabel-variabel independennya. 


\section{c. Autokorelasi}

Tabel 11. Autokorelasi

\begin{tabular}{|c|c|c|c|c|c|c|}
\hline Model & \multicolumn{5}{|l|}{ Change Statistics } & \multirow[t]{2}{*}{ Durbin-Watson } \\
\hline & R Square Change & F Change & $\mathrm{df1}$ & $\mathrm{df} 2$ & Sig. F Change & \\
\hline 1 & .127 & 2.494 & 5 & 86 & .037 & 1.705 \\
\hline
\end{tabular}

a Predictors: (Constant), EPSP, NPS, PPS, RUDW, RAUD

b Dependent Variable: IR1h

Dengan $n=92, k=5$ model regresi IR1h memiliki $d_{L}=1.54$ dan $d_{U}=1.78$. Hasil uji autokorelasi diatas menunjukkan nilai $D W=1.705$. Nilai $D W$ tersebut diantara $d_{L}$ dan $d_{U}$ sehingga tidak dapat diambil kesimpulan yang pasti mengenai model regresi IR1h.

\section{Model Regresi Return 1 Bulan}

$$
\begin{aligned}
& R 1 b_{t}=6.158-0.001 R U D W_{t}-0.038 R A U D_{t}-0.515 N P S_{t}-0.072 P P S_{t} \\
& -0.015 \operatorname{EPSP}_{t}+\varepsilon_{t}
\end{aligned}
$$

\section{Uji Keberartian Model (Uji F)}

\begin{tabular}{|c|c|c|c|c|c|c|}
\hline Model & & Sum of Squares & $\mathrm{df}$ & Mean Square & $\mathrm{F}$ & Sig. \\
\hline 1 & $\begin{array}{l}\text { Regression } \\
\text { Residual } \\
\text { Total }\end{array}$ & $\begin{array}{l}8.020 \\
105.781 \\
113.802\end{array}$ & $\begin{array}{l}5 \\
86 \\
91\end{array}$ & $\begin{array}{l}1.604 \\
1.230\end{array}$ & 1.304 & $.270(a)$ \\
\hline
\end{tabular}

Tabel 12. Uji Keberartian Model

a Predictors: (Constant), EPSP, NPS, PPS, RUDW, RAUD

b Dependent Variable: R1b

Tabel diatas menunjukkan bahwa nilai probabilitas F 0.270 lebih besar dari $\alpha=0.05$. Dengan demikian dapat dikatakan bahwa secara bersama-sama variabel independen tidak mempunyai hubungan yang signifikan dengan variabel dependen.

\section{Uji Koefisien Regresi (Uji t)}

\begin{tabular}{|c|c|c|c|c|c|c|}
\hline \multirow[t]{2}{*}{ Model } & & \multicolumn{2}{|c|}{$\begin{array}{l}\text { Unstandardized } \\
\text { Coefficients }\end{array}$} & \multirow{2}{*}{$\begin{array}{l}\text { Standardized } \\
\text { Coefficients } \\
\text { Beta } \\
\end{array}$} & \multirow[t]{2}{*}{$\mathrm{t}$} & \multirow[t]{2}{*}{ Sig. } \\
\hline & & B & Std. Error & & & \\
\hline 1 & $\begin{array}{l}\text { (Constant) } \\
\text { RUDW } \\
\text { RAUD } \\
\text { NPS }\end{array}$ & $\begin{array}{l}6.158 \\
-.001 \\
-.038 \\
-.515\end{array}$ & $\begin{array}{l}2.567 \\
.064 \\
.274 \\
.241\end{array}$ & $\begin{array}{l}-.001 \\
-.017 \\
-.252\end{array}$ & $\begin{array}{l}2.399 \\
-.011 \\
-.140 \\
-2.135\end{array}$ & $\begin{array}{l}.019 \\
.991 \\
.889 \\
.036\end{array}$ \\
\hline
\end{tabular}

Tabel 13. Uji Koefisien Regresi 


\begin{tabular}{|l|l|l|l|l|l|} 
PPS & -.072 & .107 & -.071 & -.668 & .506 \\
EPSP & -.015 & .021 & -.082 & -.732 & .466 \\
\hline
\end{tabular}

a Dependent Variable: R1b

(continued)

Tabel Hasil Uji t menunjukkan tidak ada pengaruh yang signifikan dari variabel independen RUDW, RAUD, PPS, dan EPSP terhadap variabel dependen R1b dikarenakan semua probabilitas variabel-variabel independen tersebut lebih besar dari $\alpha=0.05$. Semua varibel memiliki pengaruh negatif terhadap R1b. Dengan demikian hanya variabel NPS yang berpengaruh signfikan terhadap model regresi Return 1 Bulan.

\section{Uji Koefisien Determinasi $\left(\mathbf{R}^{2}\right)$}

Tabel 14. Uji Koefisien Determinasi

\begin{tabular}{|l|l|l|l|l|}
\hline Model & R & R Square & Adjusted R Square & Std. Error of the Estimate \\
\hline 1 & $.265(\mathrm{a})$ & .070 & .016 & 1.1090609 \\
\hline
\end{tabular}

a Predictors: (Constant), EPSP, NPS, PPS, RUDW, RAUD

b Dependent Variable: R1b

Pada Tabel Uji Koefisien Determinasi $\left(\mathrm{R}^{2}\right)$ ditunjukkan bahwa $\mathrm{R}^{2}=0.070$ yang berarti hanya $7 \%$ variasi variabel independen dapat menjelaskan variabel dependen $\mathrm{R} 1 \mathrm{~b}$, sedangkan sisanya 93\% dijelaskan oleh variabel lain.

\section{Uji Asumsi Klasik \\ a. Normalitas}

Normal P-P Plot of Regression Standardized Residual

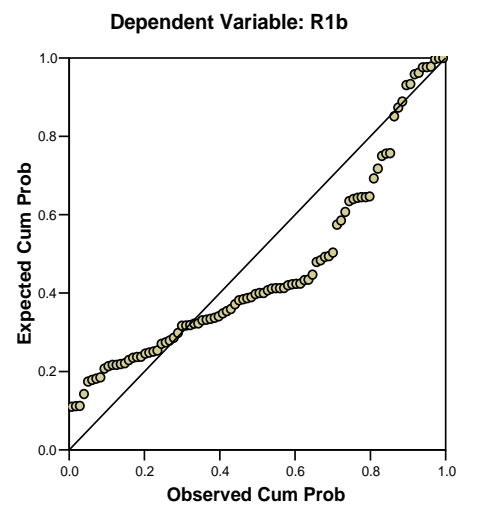

Grafik diatas memperlihatkan penyebaran titik-titik masih berada di sekitar garis diagonal. Sehingga, dapat disimpulkan model regresi R1b sudah memenuhi asumsi normalitas.

\section{b. Multikolinearitas}

Penggunaan variabel-variabel independen pada model regresi R1b sama dengan model regresi IR1h. Sehingga tidak ada masalah multikolinieritas dalam model regresi R1b. 


\section{c. Autokorelasi}

Tabel 15. Autokorelasi

\begin{tabular}{|c|c|c|c|c|c|c|}
\hline Model & \multicolumn{5}{|l|}{ Change Statistics } & \multirow[t]{2}{*}{ Durbin-Watson } \\
\hline & R Square Change & F Change & $\mathrm{df1}$ & $\mathrm{df} 2$ & Sig. F Change & \\
\hline 1 & .070 & 1.304 & 5 & 86 & .270 & 2.063 \\
\hline
\end{tabular}

a Predictors: (Constant), EPSP, NPS, PPS, RUDW, RAUD

b Dependent Variable: R1b

Dengan $n=92, k=5$ model regresi $R 1 b$ memiliki $d_{L}=1.54$ dan $d_{U}=1.78$. Hasil uji autokorelasi diatas menunjukkan nilai $\mathrm{DW}=2.063>\mathrm{d}_{\mathrm{U}}=1.78$ sehingga dapat dinyatakan model regresi R1b tidak memilki autokorelasi yang positif. Dengan demikian model regresi ini telah memenuhi asumsi autokorelasi.

\section{Model Regresi Return 1 Tahun}

$$
R 1 t_{t}=0.069-0.355 I R 1 h_{t}+0.471 R 1 b_{t}+\varepsilon_{t}
$$

\section{Uji Keberartian Model (Uji F)}

Tabel Hasil Uji F menunjukkan nilai probabilitas F 0.005 dimana lebih kecil dari $\alpha=0.05$. Ini berarti secara bersama-sama variabel independen mempunyai hubungan signifikan dengan variabel dependen.

Tabel 16. Uji Keberartian Model

\begin{tabular}{|l|l|l|l|l|l|l|}
\hline Model & & Sum of Squares & Df & Mean Square & F & Sig. \\
\hline 1 & Regression & 13.768 & 2 & 6.882 & 5.640 & $.005(\mathrm{a})$ \\
& Residual & 104.816 & 86 & 1.219 & & \\
& Total & 118.565 & 88 & & & \\
\hline
\end{tabular}

2. Uji Koefisien Regresi (Uji t)

Tabel 17. Uji Koefisien Regresi

\begin{tabular}{|c|c|c|c|c|c|c|}
\hline \multirow[t]{2}{*}{ Model } & & \multicolumn{2}{|c|}{$\begin{array}{l}\text { Unstandardized } \\
\text { Coefficients }\end{array}$} & \multirow{2}{*}{\begin{tabular}{|l|}
$\begin{array}{l}\text { Standardized } \\
\text { Coefficients }\end{array}$ \\
Beta \\
\end{tabular}} & \multirow[t]{2}{*}{$\mathrm{t}$} & \multirow[t]{2}{*}{ Sig. } \\
\hline & & $\mathrm{B}$ & Std. Error & & & \\
\hline 1 & $\begin{array}{l}\text { (Constant) } \\
\text { IR1h } \\
\text { R1b }\end{array}$ & $\begin{array}{l}.069 \\
-.355 \\
.471\end{array}$ & $\begin{array}{l}.142 \\
.264 \\
.153\end{array}$ & $\begin{array}{l}-.200 \\
.459\end{array}$ & $\begin{array}{l}.487 \\
-1.343 \\
3.077\end{array}$ & $\begin{array}{l}.628 \\
.183 \\
.003\end{array}$ \\
\hline
\end{tabular}

a Dependent Variable: R1t

Probabilitas IR1h 0.183 lebih besar dari $\alpha=0.05$. Hal ini berarti initial return 1 hari memiliki hubungan negatif yang tidak signifikan terhadap return satu tahun. Berbeda dengan return 1 bulan yang memiliki hubungan positif yang signifikan terhadap return 1 tahundimana probabilitas R1b 0.003 lebih kecil dari $\alpha=0.05$. 


\section{Uji Koefisien Determinasi $\left(\mathbf{R}^{2}\right)$}

Berdasarkan Tabel dibawah, dapat dijelaskan bahwa hanya $11.6 \%$ variasi variabel independen, IR1h dan R1b, dapat menjelaskan variasi variabel dependen R1t. Sedangkan sisanya $88.4 \%$ dijelaskan oleh variabel lain.

Tabel 18. Uji Koefisien Determinasi

\begin{tabular}{|l|l|l|l|l|}
\hline Model & R & R Square & Adjusted R Square & Std. Error of the Estimate \\
\hline 1 & $.341(\mathrm{a})$ & .116 & .095 & 1.1039096 \\
\hline
\end{tabular}

a Predictors: (Constant), R1b, IR1h

b Dependent Variable: R1t

4. Uji Asumsi Klasik

a. Normalitas

Grafik Hasil Uji Normalitas model regresi Return 1 Tahun memperlihatkan penyebaran titik-titik masih berkisar disekitar garis diagonal. Dengan demikian dapat disimpulkan bahwa model regresi $\mathrm{R} 1 \mathrm{t}$ telah memenuhi asumsi normalitas.

\section{b. Multikolinieritas}

Dari hasil uji multikolinieritas didapatkan bahwa nilai tolerance variabel IR1h dan R1b lebih besar dari 0.1 dan nilai VIF lebih kecil dari 10. sehingga dapat dikatakan tidak

Normal P-P Plot of Regression Standardized Residual

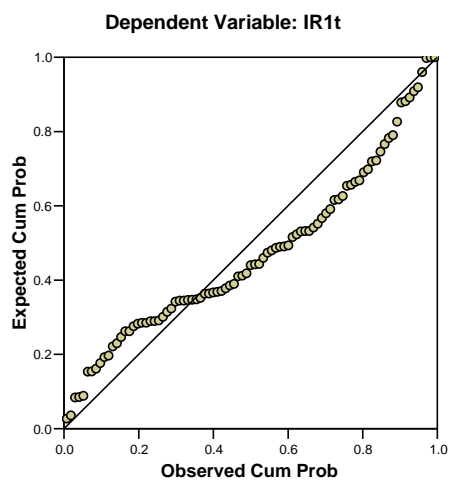
terdapat masalah multikolinieritas dalam model regresi R1t.

Tabel 19. Multikolinieritas

\begin{tabular}{|c|c|c|c|}
\hline \multirow[t]{2}{*}{ Model } & & \multicolumn{2}{|c|}{ Collinearity Statistics } \\
\hline & & Tolerance & VIF \\
\hline 1 & $\begin{array}{l}\text { (Constant) } \\
\text { IR1h } \\
\text { R1b }\end{array}$ & $\begin{array}{l}.462 \\
.462\end{array}$ & $\begin{array}{l}2.164 \\
2.164\end{array}$ \\
\hline
\end{tabular}

d. Autokorelasi

a Dependent Variable: R1t

Tabel 20. Autokorelasi

\begin{tabular}{|l|l|l|l|l|l|}
\hline Model & R & R Square & Adjusted R Square & Std. Error of the Estimate & Durbin-Watson \\
\hline 1 & $.341(\mathrm{a})$ & .116 & .096 & 1.1039092 & 1.947 \\
\hline
\end{tabular}

a Predictors: (Constant), R1b, IR1h

b Dependent Variable: R1t 
Berdasarkan Tabel Critical Values $d_{L}$ dan $d_{U}$ Durbin-Watson Statistic D didapatkan untuk $\mathrm{n}=89, \mathrm{k}=2$ memiliki $\mathrm{d}_{\mathrm{L}}=1.61$ dan $\mathrm{d}_{\mathrm{U}}=1.70$. Hasil uji autokorelasi didapatkan nilai $\mathrm{DW}=1.947>\mathrm{d}_{\mathrm{U}}=1.70$ menunjukkan tidak ada bukti autokorelasi yang positif antara nilai residu. Dengan demikian model regresi yang dipakai telah memenuhi asumsi autokorelasi.

\section{Kesimpulan}

Berdasarkan hasil analisis, maka peneliti mengambil kesimpulan sebagai berikut :

1. Reputasi underwriter secara positif tidak berpengaruh signifikan terhadap initial return 1 hari.

2. Reputasi auditor secara positif tidak berpengaruh signifikan terhadap initial return 1 hari.

3. Nilai penawaran saham secara negatif berpengaruh signifikan terhadap initial return 1 hari.

4. Prosentase penawaran saham secara negatif tidak berpengaruh signifikan terhadap initial return 1 hari.

5. Earnings per share terhadap harga IPO secara negatif tidak berpengaruh signifikan terhadap initial return 1 hari.

6. Reputasi underwriter secara negarif tidak berpengaruh signifikan terhadap return 1 bulan.

7. Reputasi auditor secara negatif tidak berpengaruh signifikan terhadap return 1 bulan.

8. Nilai penawaran saham secara negatif berpengaruh signifikan terhadap return 1 bulan.

9. Prosentase penawaran saham secara negatif tidak berpengaruh signifikan terhadap return 1 bulan.

10. Earnings per share terhadap harga IPO secara negatif tidak berpengaruh signifikan terhadap return 1 bulan.

11. Initial return 1 hari secara negatif tidak berpengaruh signifikan terhadap return satu tahun.

12. Return 1 bulan secara positif berpengaruh signifikan terhadap return satu tahun.

13. Reputasi underwriter, reputasi auditor, nilai penawaran saham, prosentase penawaran saham, dan earnings per share terhadap harga IPO secara bersama-sama berpengaruh signifikan terhadap initial return 1 hari setelah IPO.

14. Reputasi underwriter, reputasi auditor, nilai penawaran saham, prosentase penawaran saham, dan earnings per share terhadap harga IPO secara bersama-sama tidak berpengaruh signifikan terhadap return 1 bulan setelah IPO.

15. Initial return 1 hari dan return 1 bulan secara bersama-sama berpengaruh signifikan terhadap return 1 tahun setelah IPO.

\section{Saran}

lain:

Dengan selesainya penelitian ini, peneliti ingin memberikan beberapa saran antara

1. Bagi perusahaan yang akan melakukan IPO, sekiranya lebih memperhatikan faktor nilai penawaran saham. Sehingga dapat meminimalisir kerugian akibat positive initial return yang terlalu tinggi.

2. Bagi investor yang tertarik untuk investasi pada perusahaan yang baru IPO dapat mempertimbangkan return 1 bulan sesudah IPO jika ingin mendapatkan positive return saat 1 tahunsesudah IPO.

3. Penambahan variabel baru untuk mengembangkan penelitian sehingga faktor-faktor yang mempengaruhi initial return 1 hari, 1 bulan, dan pengaruh terhadap return 1 tahunsesudah IPO akan lebih mudah diidentifikasi. 


\section{DAFTAR PUSTAKA}

Arens, Alvin A., \& Loebbecke, James K. (1997). Auditing Pendekatan Terpadu. Diadapatasi oleh: Amir Abadi Jusuf, Buku 1, Cetakan kedua, Jakarta:Salemba Empat.

Brigham, Eugene F., \& Ehrhardt. (2002). Financial Management Theory and Practice. $10^{\text {th }}$ Edition. Orlando:Harcourt College Publisher.

Bursa Efek Jakarta. (1999). Indonesian Capital Market Directory. Institute For Economic And Financial Research.

Bursa Efek Jakarta. (2000). Indonesian Capital Market Directory. Institute For Economic And Financial Research.

Bursa Efek Jakarta. (2001). Indonesian Capital Market Directory. Institute For Economic And Financial Research.

Bursa Efek Jakarta. (2002). Indonesian Capital Market Directory. Institute For Economic And Financial Research.

Bursa Efek Jakarta. (2003). Indonesian Capital Market Directory. Institute For Economic And Financial Research.

Bursa Efek Jakarta. (2004). Indonesian Capital Market Directory. Institute For Economic And Financial Research.

Bursa Efek Jakarta. (2005). Indonesian Capital Market Directory. Institute For Economic And Financial Research.

Carter, Richard. \& Manaster, Steven. (1990). Initial Public Offering and Underwriter Reputation. The Journal of Finance, Vol. XLV,No 4,1045-1067.

Cooper, Donald R., \& C. William Emory. (1999). Metode Penelitian Bisnis. Diterjemahkan oleh: Ellen Gunawan dan Imam Nurmawan, Edisi Ke5, Jilid 1, Jakarta: Penerbit Erlangga.

Dahlan Siamat. (2004). Manajemen Lembaga Keuangan. Edisi ke-4, Jakarta: Lembaga Penerbit Fakultas Ekonomi Universitas Indonesia.

Daljono. (2000). Analisis Faktor-faktor yang Mempengaruhi Initial Return Saham yang Listing di BEJ Tahun 1990-1997. Kumpulan Simposium Nasional Akuntansi III,556572.

Ghozali, Imam \& Mansyur, Mudrik Al. (2002). Analisis Faktor-faktor yang Mempengaruhi Tingkat Underpricing di Bursa Efek Jakarta. Jurnal Bisnis dan Akuntansi Vol 4 No 1,74-88. 
Johnson, James M., \& Miller, Robert E. (1988). Investment Banker Prestige and the Underpricing of Initial Public Offerings. Financial Management 17 (Summer),19-29.

Keown, Arthur J., Martin, John D., Petty, J. William, \& Scott, David F. (2005). Financial Management:Principles and Applications. $10^{\text {th }}$ Edition, PrenticeHall International.

Martani, Dwi (2003). Pengaruh Informasi Selama Proses Penawaran Terhadap Initial Return Perusahaan yang Listing di Bursa Efek Jakarta dari Tahun 1990-2000. Kumpulan Simposium Nasional Akuntansi IV,1299-1313.

Misnen Ardiansyah (2004). Pengaruh Variabel Keuangan terhadap Return Awal dan Return 15 Hari setelah IPO serta Moderasi Besaran Perusahaan terhadap Hubungan antara Variabel Keuangan dengan Return Awal dan Return 15 Hari Setelah IPO di Bursa Efek Jakarta. Jurnal Riset Akuntansi Indonesia Vol.7 No.2, 125-153.

Nasirwan (2000). Reputasi Penjamin Emisi, Return Awal, Return 15 Hari Sesudah IPO, dan Kinerja Perusahaan Satu Tahun Sesudah IPO di BEJ. Simposium Nasional Akuntansi III, 573-598.

Pahala \& Sembel, Roy H.M. (2005). Underwriter reputation? Who cares...?Evidence from JSX(1995-2004). Thesis.

Republik Indonesia (1995). Undang-Undang RI Nomor 8 Tahun 1995 tentang Pasar Modal. Sumber: http://www.bapepam.go.id.

Rosyati \& Sabeni, Arifin (2002). Analisis Faktor-faktor yang Mempengaruhi Underpricing Saham pada Perusahaan Go Public di Bursa Efek Jakarta (Tahun 1997-2000). Simposium Nasional Akuntansi V, 286-297.

Sembel, Roy H.M. (1996). IPO Anomalies, Truncated Excess Supply, and Heterogeneous Information. Unpublished Dissertation, J M Katz Graduate School of Business, University of Pittsburg,Pensylvania.

Trihendradi, Cornelius (2004). Langkah Mudah Memecahkan Kasus Statistik: Deskriptif, Parametrik, dan Non-Parametrik dengan SPSS 12. Yogyakarta:Penerbit Andi Offset. 